\title{
Pyramiding of Genes for Grain Protein Content, Grain Quality and Rust Resistance in Eleven Indian Bread Wheat Cultivars: A Multi-Institutional Effort
}

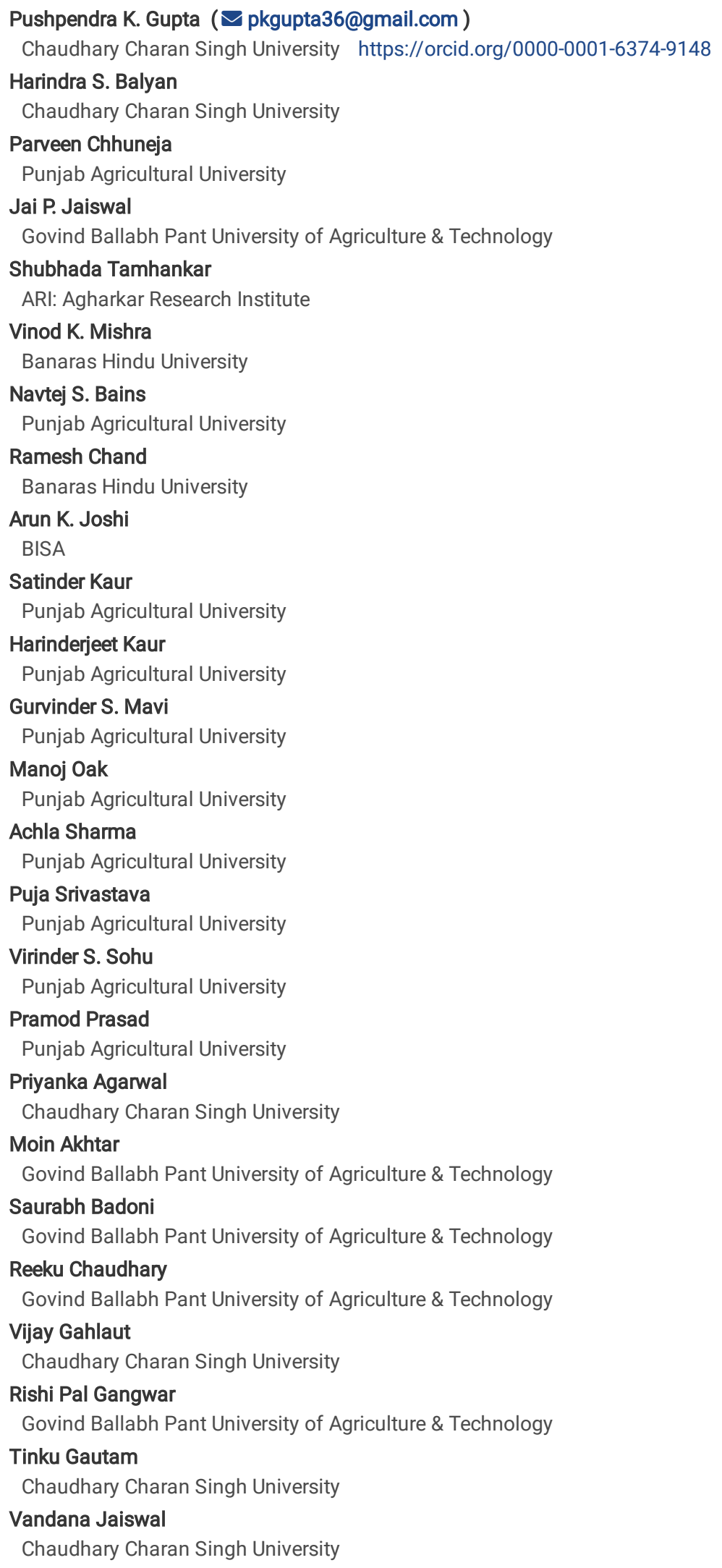




\section{Ravi Shankar Kumar}

Govind Ballabh Pant University of Agriculture \& Technology

\section{Sachin Kumar}

Chaudhary Charan Singh University

\section{Shamshad}

Punjab Agricultural University

Anupama Singh

Govind Ballabh Pant University of Agriculture \& Technology

Sandhya Taygi

Chaudhary Charan Singh University

Neeraj Kumar Vasistha

Banaras Hindu University

Manish Kumar Vishwakarma

Banaras Hindu University

\section{Research Article}

Keywords: Wheat, grain protein content, marker-assisted backcrossing, rust resistance

Posted Date: June 29th, 2021

DOl: https://doi.org/10.21203/rs.3.rs-637558/v1

License: (c) (1) This work is licensed under a Creative Commons Attribution 4.0 International License. Read Full License

Version of Record: A version of this preprint was published at Molecular Breeding on April 1st, 2022. See the published version at https://doi.org/10.1007/s11032-022-01277-w. 


\section{Abstract}

Improvement of grain protein content (GPC), loaf volume and resistance to rusts was achieved in 11 Indian wheat cultivars that are widely grown in four different agro-climatic zones of India. This involved use of marker-assisted backcrossing (MABC) for introgression and pyramiding of the following genes: (i) the high GPC gene Gpc-B1; (ii) HMW glutenin subunits $5+10$ at Glu-D1 loci, and (iii) rust resistance genes, Yr36, Yr15, Lr24 and Sr24. GPC was improved by $0.8-3.3 \%$, although high GPC was generally associated with yield penalty. Further selection among high GPC lines, allowed development of progenies with higher GPC associated with improvement in 1000-grain weight and grain yield in the following four cultivars: NI5439, UP2338, UP2382 and HUW468. The high GPC progenies (derived from NI5439) were also improved for grain quality using HMW glutenin subunits $5+10$ at G/u-D1 loci. Similarly, progenies combining high GPC and rust resistance were developed in the backgrounds of following five cultivars: Lok1, HD2967, PBW550, PBW621 and DBW1. The improved pre-bred lines developed during the present study should prove useful for development of cultivars with improved nutritional quality associated with rust resistance in future wheat breeding programmes.

\section{Introduction}

Global food and nutritional security continue to be the subjects of world-wide discussions for several decades. Therefore, major global efforts are under-way to increase food production and to improve nutritional value of the food. Although, for the last few decades, we have been in a comfortable situation with respect to meeting the demands of food production for growing world population, the problems of undernourishment and malnutrition have not been addressed adequately. As a result of recent efforts, although a decline in undernourished population was witnessed, a reverse trend started again after 2015, so that currently $9-11 \%$ of world population suffers from undernourishment, and this is likely to increase further (by $\sim 0.8$ to $1.0 \%$ ) by 2030 , when $>850$ million people are predicted to suffer with hunger and undernourishment/malnutrition (Purugganan and Jackson 2021). Particularly in India, energy malnutrition alone causes stunting ( $48 \%$ children), wasting ( $20 \%$ children) and low body weight ( $43 \%$ children) in children under the age of five, which is highest in the world (Bhutia 2014) and therefore, is a matter of concern.

While addressing the above problem of hunger, undernourishment and malnutrition, wheat crop deserves major attention, since it is the second most important crop after maize in terms of staple food and second most important crop after rice in terms of food and nutritional security. While efforts are being made to increase global wheat production from the current level of 764.39 Mt during 2019/2020 (http://www.worldagriculturalproduction. com/crops/wheat.aspx) to at least $\sim 850 \mathrm{Mt}$ in the year 2050, efforts are also underway to improve nutritional quality of wheat grain, both in terms of grain protein content (GPC) and mineral nutrients like Zn and Fe using the approach of biofortification (Gupta et al. 2020, 2021). It is estimated that 20.4\% of protein needs of growing human population across the world are met by wheat grain (https://www.wheatinitiative.org/), so that the problem of protein deficiency can be partly addressed through increase in GPC in wheat to provide a healthy diet; other components of nutrition are fiber and minor quantities of lipids, vitamins, minerals, and phytochemicals, which are also being addressed (Shewry and Hey 2015).

Considerable genetic variation for GPC is known to occur in wheat and the genetic architecture of GPC seems to be complex indeed (see Balyan et al. 2013), so that QTLs determining protein content in cultivated and wild wheats are now known to occur on all the 21 wheat chromosomes (for a summary of QTLs for protein content, consult wheatQTdb at http://wheatqtldb.net/Quality.php; Singh et al. 2021). However, none of these QTL is a major QTL and the expression of known QTLs is unstable and influenced by QTL x QTL interactions and QTL $x$ environment interactions, making them relatively unsuitable for marker-assisted breeding (Prasad et al. 1999, 2003; Dholakia et al. 2001; Kulwal et al. 2005; Kumar et al. 2006; Krishanappa et al. 2017; Goel et al. 2019). In contrast to this gloomy picture, the gene $G p c-B 1$ that was discovered originally from wild emmer wheat (Triticum turgidum var dicoccoides) has become the gene of choice and has been widely exploited during the last decade. The gene Gpc-B1 encodes a NAC transcription factor that accelerates senescence resulting in increased mobilization and transfer of nitrogen $(\mathrm{N})$ and minerals like zinc $(\mathrm{Zn})$ and iron (Fe) to the developing grains (Uauy et al. 2006). Therefore, lines expressing this allele contain relatively higher contents of GPC, Zn, and Fe in their grain (Distelfeld et al. 2006; Uauy et al. 2006). When transferred to hard red spring wheat, Gpc-B1 leads to an increase in GPC by up to $3 \%$ over the parental line (Khan et al. 2000). In the past, the derived lines carrying Gpc-B1 were evaluated in 40 environments in seven different countries (for a review Tabbita et al. 2017). As a result, several cultivars for bread wheat (Lassik, Farnum, Lillian, Somerset, Burnsid) and durum wheat (Westmore and Desert King High Protein) with high GPC have been developed (for reviews see Balyan et al. 2013; Gupta et al. 2020, 2021). Recently, in India also, many advanced lines containing Gpc-B1 gene have been developed in different genetic backgrounds including cv. PBW550 at PAU, Ludhiana. We hope that some of these lines will eventually be released as high grain protein wheat cultivars in foreseeable future. Overall, these studies established that Gpc-B1 increases GPC, Zn, and Fe contents, although it has a marginally negative impact on grain yield (Tabbita et al. 2017). However, high GPC lines containing Gpc-B1 with no yield penalty have also been developed (Kumar et al. 2011).

Besides improved nutritional quality, technological properties of the wheat flour are also important for developing suitable end-products like bread/chapati (Indian flat bread). The seed storage proteins ( 50\% of the total protein) determine the technological properties of the wheat flour (Gupta et al. 1998). Among the storage proteins, the quantity and quality of glutenin proteins are the major determinants of the elasticity of wheat flour dough contributing to the quality of bread and chapati (D'Ovidio and Masci 2004; Figueroa et al. 2009; Payne et al. 1979). The composition of high molecular weight glutenin subunits (HMW-GS) determines the wheat baking quality (Dhaka and Khatkar 2015; Dobraszczyk and Morgenstern 2003). The HMW-GS 5+10 combination encoded by complex Glu-D1 locus are associated with good baking quality and is therefore preferred over $2+10$ subunit combination, which is associated with poor baking quality (see Nucia et al. 2019). However, the HMW-GS 5+10 are not common among Indian bread wheat cultivars (Ram 2003, Ram et al. 2015, Patil et al. 2015). Therefore, there is a need for the introgression and pyramiding of HMW-GS 5+10 along with high GPC into elite Indian bread wheat cultivars to improve the technological properties of the flour. 
In the present multi-institutional study, five institutions worked together to introgress the high GPC gene Gpc-B1 into 11 elite Indian bread wheat cultivars (including cultivars that are grown in different parts of the country) using marker-assisted backcross breeding (MABB). In one of these 11 cultivars, used as a representative, GPC was also pyramided with HMW-GS 5+10. The genes for resistance against yellow rust Yr15 and Yr36 (associated with Gpc-B1), leaf rust ( $L r 24)$ and stem rust ( $S r 24)$ were also pyramided over enhanced grain quality in the derived lines. The results of this collaborative study are presented in this communication.

\section{Material And Methods}

\section{Material (Recipients, Donors, and Markers)}

Recipient parents. Eleven (11) elite Indian bread wheat cultivars that were used in the present study as recipients included the following: (i) six cultivars (HD2967, PBW550 (Yr15), DBW17, PBW621, UP2338, and UP2382) cultivated in north western plain zone, (ii) two cultivars (HUW234 and HUW468) grown in north eastern plain zone, (iii) two cultivars (MACS 2496 and NI5439) used in peninsular zone and the (iv) a solitary cultivar (Lok1) is cultivated in central zone (Fig. S1). All recipient cultivars are cultivated under timely or late sown (HUW234) and irrigated conditions; only cv. NI5439 of peninsular zone is recommended for cultivation under rainfed and timely sown conditions.

Donors with desirable genes. The donors used in the present study included the following: (i) PBW343 (Gpc-B1/Yr36+Lr24), which is an improved version of an erstwhile popular cultivar PBW343, which later became susceptible to yellow rust, and was also resurrected through pyramiding of leaf and stripe rust resistance genes (Kumar et al. 2011; Sharma et al. 2021). (ii) Glupro (Gpc-B1/Yr36), an exotic genotype earlier developed by Jorge Dubcovsky and his team at the University of California (Davis), USA (Khan et al. 2000; Uauy et al. 2006).

Markers for foreground and background selections. For foreground selection following markers were used: (i) Gpc-B1 gene: Xuhw89, a marker closely linked (0.1 cM) to Gpc-B1 (Distelfeld et al. 2006), and Xucw108, a gene-based co-dominant functional marker (Uauy et al. 2006). (ii) Lr24: SCAR marker XSCS73 $_{719}$ (Prabhu et al. 2004). (iii) Yr15: gwm413 (Murphy et al. 2009); (iv) Yr36 (linked to Gpc-B1) gene-based markers: Xucw130 (Fu et el. 2009 ). For background selection, polymorphic SSR markers ranging in number from 102 to 126 were used.

\section{Scheme for MABB}

The breeding scheme followed for MABB is presented in Fig. 1. Eleven (11) crosses were made involving 11 recipient and the two donor genotypes [the donor genotype PBW343 (Gpc-B1/Yr36+Lr24) was used for eight recipients and Glupro (Gpc-B1/Yr36) was used for the remaining three recipients]. In $\mathrm{BC}_{1} \mathrm{~F}_{1}$ to $\mathrm{BC}_{3} \mathrm{~F}_{2}$ populations, foreground selection was exercised in order to recover plants heterozygous/homozygous for the desired allele from the donor parent. The positive plants in $\mathrm{BC}_{1} \mathrm{~F}_{2} / \mathrm{BC}_{2} \mathrm{~F}_{2} / \mathrm{BC}_{3} \mathrm{~F}_{2}$ were selfed to obtain $\mathrm{BC}_{1} \mathrm{~F}_{3} / \mathrm{BC}_{2} \mathrm{~F}_{3} / \mathrm{BC}_{3} \mathrm{~F}_{3}$ progenies, which were advanced up to $B C_{1-3} \mathrm{~F}_{4-7}$ generations before conducting field trial of MABB-derived progenies. Background selection accompanied the foreground selection up to $B C_{1} F_{3} / B_{2} F_{3} / B_{3} F_{3}$ generations; in some cases, background selection was performed after the recovery of the homozygous and stable progenies in order to estimate the percent recurrent parent genome recovery. Phenotypic selection was carried out whenever necessary in order to derive agronomically superior progenies.

\section{Laboratory Experiments}

DNA isolation, PCR, and marker analysis. DNA isolation was carried out using leaf samples of 30-40 days old plants by the CTAB method following SaghaiMaroof et al. (1984) with some modifications. DNA quality was checked on 1\% agarose gels and quantification was carried out using Pico2000. Polymerase chain reaction (PCR) was carried out in 12-20 $\mu \mathrm{L}$ reaction volume containing 25-50 ng of genomic DNA, 1-Unit Taq polymerase (Sigma-Aldrich, USA/Bangalore Genie, India), $0.02 \mathrm{mM}$ of each of four dNTPs (Sigma-Aldrich, USA/Bangalore Genie, India), $0.2 \mu \mathrm{M}$ of forward and reverse primers (synthesized by IDT, USA), and 1X PCR buffer (10 mM Tris- $\mathrm{HCl} \mathrm{pH} \mathrm{8.4).} \mathrm{PCR} \mathrm{was} \mathrm{performed} \mathrm{using} \mathrm{Applied} \mathrm{Biosystem's} \mathrm{Thermal} \mathrm{Cycler} \mathrm{using} \mathrm{the} \mathrm{following}$ PCR profile: $94{ }^{\circ} \mathrm{C}$ for $4-5 \mathrm{~min}$, followed by 35 cycles of $94^{\circ} \mathrm{C}$ for $30-60 \mathrm{~s}, 57-60^{\circ} \mathrm{C}$ (depending on the primer sequences) for $30 \mathrm{~s}$, and $72{ }^{\circ} \mathrm{C}$ for 1 min, with a final extension at $72{ }^{\circ} \mathrm{C}$ for $7-8 \mathrm{~min}$. The amplified products were resolved on $2-2.5 \%$ agarose gel and visualized following ethidium bromide staining or on $6 \%$ PAGE and visualized following silver staining.

Grain quality tests: Percent grain protein content (GPC) was determined using Near-Infrared Transmittance in 1241 Grain Analyzer (FOSS, Sweden). The contents of $\mathrm{Fe}(\mathrm{ppm})$ and $\mathrm{Zn}(\mathrm{ppm})$ in the grains were estimated using Energy-Dispersive X-ray fluorescence (EDXRF spectrometer X-Supreme8000) (Paltridge et al. 2012). Sedimentation volume was worked out using micro-SDS sedimentation volume (MSDS-SV) test following Dick and Quick (1983).

Micro-baking for loaf volume: For estimation of loaf volume, the formulation included flour (100 parts), water (65\%), salt (2 parts), fresh yeast (2.5 parts), which were mixed in the 10-g mixograph. The resulting dough which was molded, rested for 20 min at $28^{\circ} \mathrm{C}$, remolded, proofed for 45 min at $28^{\circ} \mathrm{C}$ and $90 \%$ relative humidity, and baked at $200^{\circ} \mathrm{C}$ for $17 \mathrm{~min}$ (Gras and Bekes 1996). Loaf volume was measured by the mustard seed displacement method. Baking tests were done in duplicate.

SDS-PAGE (polyacrylamide gel electrophoresis): The proteins of flour samples were extracted and fractionated in 10\% polyacrylamide gels using the method of Laemmli (1970) as modified by Payne et al. (1980).

\section{Field Experiments}


The details of field experiments conducted for evaluation of MABB-derived progenies in the background of 11 recipient cultivars are summarized in Table S1. The number of progenies in the different recipient genetic backgrounds varied from 1 to 24 . The experiments were conducted in randomized block designs each with 2-3 replications over 1-3 years and 1-5 locations. The plot size differed in different experiments with the largest plot size comprising 12 rows of $6 \mathrm{~m}$ each and smallest plot size comprising 4 rows of $3 \mathrm{~m}$ each (Table S1). Standard cultural practices were followed to raise the crop at different locations and years. In each plot, data were recorded on 1000-grain weight (g), grain yield (t/ha or q/ha), and GPC (\%).

\section{Screening for Rusts}

Glass-house screening against three rusts. MAS-derived progenies in the backgrounds of cvs. Lok1 and HD2967 were screened for resistance to three rusts. Altogether, 16 pathotypes of the three rust pathogens occurring in different wheat-growing regions of India were used for this purpose. Screening for rust resistance of the MAS-derived progenies along with their recipient parents was carried out as described in Gautam et al. (2020). The seedlings were assayed for the infection types (ITs) against each pathotype at 15 days post-inoculation following Stakman et al. (1962). IT0 indicated resistant; ITs 1, 12, 2- 2 , and $22^{+}$indicated moderately resistant; ITs 23 and 3 indicated moderately susceptible; and ITs $33^{+}$and $3^{+}$indicated susceptible. ITs $12,22^{+}, 23$, and $33^{+}$were based on the following criteria: 12 = small uredia with distinct chlorotic or necrotic areas; $22^{+}=$uredia size similar to IT 2 but with more sporulation; $23=$ same uredia size as for IT 3 but chlorosis is more pronounced; and $33^{+}=$large uredia, coalescing with minor chlorosis or necrosis. Plus (+) and minus (-) signs indicate variation within a given infection type.

Field screening against leaf rust and stripe rust: Screening of MAS-derived progenies in the backgrounds of three recipient cvs. PBW550 (Yr15), DBW17, and PBW621 was done in field under artificial rust epidemics created by spraying the experimental material with the mixture of uredinospores of prevalent races of stripe rust (78S84, 49S119 196, and 110S119) and leaf rust (077-5, 104-2 + unknown races collected from farmer's field). Details of races and their virulence formulae are available elsewhere (Sharma et al. 2021).

For screening of the progenies for rust resistance under field conditions, the seeds of the progenies and the parents were planted in a non-replicated augmented block design in paired rows of $1 \mathrm{~m}$. The distance within the paired rows was $22 \mathrm{~cm}$ and between two paired rows was $30 \mathrm{~cm}$. The planting of the seed material was done in the first fortnight of November each year. PBW621, PBW550, DBW17, PBW343, Agra local (for stripe rust and leaf rust) andC306 (for brown rust), each susceptible to a mixture of prevalent pathotypes having virulence for genes under consideration were planted as infector rows (at every $7^{\text {th }}$ paired row) and in spreader rows (perpendicular to the $1 \mathrm{~m}$ paired rows) surrounding the plot for establishing sufficient inoculum. To ensure uniform disease distribution, rust infected pots were placed in fields between the experimental materials, and the spores that appeared naturally in the spreader rows were used to inoculate the infector rows.

For creating stripe rust epidemics, repeated spray inoculations with uredinospores of Puccinia striiformis were carried out. The inoculation was carried out in evening with an ultralow volume sprayer on alternate days beginning from the end of December to the end of January till stripe rust appeared on the susceptible checks/parents. For this purpose, the infected leaves of susceptible host (which was pre-inoculated to multiply the pathogen) were collected and immersed in water for extracting uredinospores. The inoculum was prepared by suspending rust uredinospores (@5.6 g/ha, which equates to 1000 spores per plant (Imtiaz et al. 2003) in 10 I of water using 5-7 drops of Tween-20.

The response to rusts was recorded at the reproductive stage using disease severity (DS) and infection response (IR) as the two measures according to the modified Cobb scale (Peterson et al. 1948). DS was measured as an estimation of percentage coverage $(0,5,10,18720,40,60,80$, and 100$)$ of rust pustules (uredinia) seen on the flag leaf. IR was scored as a reaction of the host to rust infection and was categorised as $0=i m m u n e ; R=$ resistant, $M R=$ moderately resistant; $\mathrm{MS}=$ moderately susceptible and $\mathrm{S}=$ susceptible. Data were recorded three times at equal intervals (starting mid-January) when the flag leaves of the susceptible check cultivars showed a disease score of 80S (DS: 80; IR: S). Out of these three scores of a test line, the highest score toward susceptibility was used for the subsequent analysis.

\section{Statistical analysis}

Means and ANOVA: The means were calculated using Excel. The analysis of variance (ANOVA) was carried out using SPSS Statistics for Windows, version 16.0 (SPSS Inc., Chicago, III., USA).

Estimation of the recovery of recipient genome (RPG): The recovery of $R P G$ was estimated using the following formula: $R P G=[(X+1 / 2 Y) / N] x 100$. Where, $X$ is the number of homozygous marker loci for recurrent parent allele, $\mathrm{Y}$ is the number of heterozygous marker loci for the parental alleles and $\mathrm{N}$ is the total number of parental polymorphic markers used for screening.

\section{Results And Discussion}

Marker-assisted selection (MAS) is routinely used now to supplement conventional plant breeding (Collard and Mackill 2008; Gupta et al. 2010; Jiang 2013). Among different breeding approaches, marker-assisted backcross breeding (MABB), is the most widely used for improvement of an existing elite cultivar/line for traits like disease resistance, grain quality and sometimes also for abiotic stress tolerance (such as submergence tolerance in rice and preharvest sprouting tolerance in wheat). MABB is mostly used for improvement of traits controlled by major genes and is not suitable for improvement of a trait that is controlled by a large number of minor genes (Hospital et al. 2003; Francia et al. 2005; Collard and Mackill, 2008; Kumar et al. 2010; Tyagi et al. 2014; Giaever et al. 2017; Gautam et al. 2021). During the present study, MABB was used for improving GPC and for all 11 cultivars, rust resistance for five cultivars, and gluten strength for only one cultivar, namely, NI5439. 


\section{Grain protein content (GPC) and grain yield}

The introgression of Gpc-B1 (high GPC gene) through MABB (involving foreground and background selections; Fig. 2a, b, d) into 11 Indian wheat cultivars was straight-forward and led to the successful development of improved lines despite significant genotype $\mathrm{x}$ environment interaction for GPC (Tables S2S8) that was reported in several earlier studies (Kumar et al. 2011; Carter et al. 2012; Singh et al. 2018). The number of progenies with improved GPC ranged from 1 to 16 for individual recipients (Supplementary Table S9). GPC level in these lines ranged from $12.4 \%$ (against $11.6 \%$ in recipient parent UP2338) to $17.2 \%$ (13.9\% in recipient parent NI5439) (Table 1). This amounted to an increase of $0.8 \%$ (in the background of UP2338) to $3.3 \%$ (in the background of NI5439) (Table 1), which is not very different from the results of some earlier studies (Khan et al. 2000; Kumar et al. 2011; Balyan et al. 2013; Tyagi et al. 2014; for reviews, see Tabbita et al. 2017; Gautam et al. 2020).

Two of the 11 recurrent parents (MACS2496 and N15439) and their derived progenies had relatively higher GPC than the rest of the recurrent parents and their progenies. These two recurrent parents are popular varieties of peninsular zone and the progenies in these backgrounds were evaluated at Pune location (located in the peninsular zone). It is well known that the GPC is higher in varieties grown in the peninsular zone and also that the high GPC was associated with higher 1000-grain weight (Mohan et al. 2017). This is contrary to the reported negative relationship between 1000-grain weight and GPC in most Indian wheat material (Nagarajan et al. 2007). Therefore, it appears that the negative relationship has been broken in the varieties grown in the peninsular zone (Mohan et al. 2017).

Despite a general negative correlation between GPC and grain yield (O'Brien and Panozzo 1988; Simmonds 1995; Brevis and Dubcovsky 2010) and reported negative effect of Gpc-B1 gene on grain yield (Tabbita et al. 2017), several progenies during the present study had improved GPC with no yield penalty (Table 2, Table S9). Following are the other desirable attributed in the improved lines obtained during the present study: (i) progenies with high GPC also had high 1000-grain weight and no yield penalty; these seven progenies were available in the background of the following recipients: MACS2496, NI5439, and HUW468 (Table 2), and (ii) 12 progenies had high GPC along with significantly higher 1000-grain weight and higher grain yield; these progenies belonged to NI5439, UP2338, UP2382 and HUW468 (Table 2).

Progenies containing higher GPC with no yield penalty due to Gpc-B1 were also reported in our earlier study (Kumar et al. 2011). It appears that the negative association between GPC and grain yield in such progenies is successfully broken allowing simultaneous improvement of both these important traits. These progenies developed during the present study need more extensive evaluations so that they may be included in the ongoing quality improvement breeding programs and may also be considered for testing in the varietal development trials.

\section{High GPC with improved grain Zn and Fe contents}

The improved progenies also had higher grain $\mathrm{Zn}$ and/or Fe contents, a trait that is associated with GPC due to the Gpc-B1 gene. This is illustrated in high GPC representative lines derived from four genotypes, (Lok1, HD2967, PBW550, and PBW621), where grain Zn and Fe were estimated and found to be improved (Table 2, Table S9). We believe that the progenies with high GPC due to Gpc-B1 in the backgrounds of the remaining eight recipients should also contain higher grain $\mathrm{Zn}$ and/or Fe concentrations. These results are in agreement with earlier reports (for a review, see Tabbita et al. 2017). Suitable explanations for this association of Gpc-B1 with high Zn and high Fe have also been provided. It is known that the high GPC gene Gpc-B1, encodes a NAC transcription factor (NAM-B1), which is known to accelerate senescence and also increases nutrient re-mobilization from leaves to grains (Uauy et al. 2006; Distelfeld et al. 2007). The Gpc-B1 gene has also been shown to regulate other genes, particularly those belonging to ZIP and YSL categories of transporters in the early senescence stage, and these transporters are eventually helpful in the export of $\mathrm{Zn}$ and Fe from the cytoplasm into the phloem and also for the biosynthesis of chelators that facilitate the phloem-based transport of Zn and Fe to the grains (Pearce et al. 2014). Therefore, the gene Gpc-B1 may also be exploited for biofortification of $\mathrm{Zn}$ and Fe in wheat grains as recently proposed by us (Gupta et al. 2021).

\section{High GPC, gluten strength, and HMW-GS 5+10}

Four high GPC progenies also had gluten strength that was comparable to that of the recipient parent NI5439, which is popular in peninsular zone (data not presented). Screening for HMW-GS showed that two of these four lines had the following HMW-GS composition: 17+18 at G/u-B1 and 5+10 at G/u-D1 and no subunit at Glu-A1 loci (Fig. 3a). It is known that the high GPC donor parent genotype PBW343+Gpc-B1/Yr36+Lr24 contained $5+10$ subunits whereas NI5439 contained 2+12 at G/u-D1. Therefore, HMW-GS 2+12 at the Glu-D1 locus in the background of recipient genotype NI5439 were successfully replaced by HMW-GS $5+10$. Micro-baking quality test showed that all the four MABB-derived progenies had $>43$ ml micro-loaf volume, which was significantly higher than the $38.5 \mathrm{ml}$ micro-loaf volume of NI 5439 (Fig. 3b). The higher loaf volume in two of the four MABB-derived progenies may be attributed to both the high GPC and HMW-GS 5+10, as reported earlier (Brevis et al. 2010). However, the higher loaf volume in the remaining two progenies which carried HMW-GS $2+12$ at Glu-D1 loci is intriguing. We speculate that this may be resolved through future studies of the gliadin content, gliadin:glutenin ratio, grain hardness, etc. in these progenies. However, the above findings suggest simultaneous improvement of GPC and baking quality in case of NI5439. The high GPC MABBderived progenies from other seven recipient parents (where PBW343+Gpc-B1/Yr36+Lr24 was used as a donor parent) could be subjected to HMW-GS allele analysis and micro-baking test in future studies to select the progenies with improved baking quality.

\section{Rust Resistance in Derived Progenies}

Progenies in the backgrounds of cvs. Lok1 and HD2967. It may be recalled that the donors used for improvement of GPC were not the same for all 11 recipients, the donor for Gpc-B1 being PBW343 (Gpc-B1/Yr36+Lr24) in case of eight of the 11 recipient genotypes (excluding PBW550, PBW621, and DBW17) and Glupro (Gpc-B1/Yr36) was used as the donor for the remaining three recipients (Table S1). Among the eight recipients, where PBW343 (Gpc$B 1 / Y r 36+L$ r24) was used as the donor, Lok1 and HD2967 were susceptible or only moderately resistant to most of the pathotypes of the leaf and stripe rusts used during the present study, although these were resistant to several stem rust pathotypes (Table 3; Fig. S2). However, the donor genotype PBW343 
(Gpc-B1/Yr36+Lr24) containing Yr36 gene for resistance to stripe rust and $L$ r24 gene for leaf rust was resistant to all the five pathotypes of leaf rust and all the seven pathotypes of stem rust used for screening in the present study, but was resistant to only one ( $T$ pathotype) of the four pathotypes of stripe rust (Table 3). Similar was the resistance pattern of the other derived progenies containing $Y r 36+L r 24$ genes against the five leaf rust pathotypes (Table 3). However, disease reaction differed for stripe rust and stem rust pathotypes in each derived line that was predominantly resistant type.

The alien gene Lr24 belonging to Agropyron elongatum introgressed during the present study (Fig. 2c) is known to confer resistance throughout the life of the plant, starting from seedling up to adult stage. After 1993, a number of leaf rust resistant wheat varieties containing Lr24 gene, which is still effective, have been released in India, although virulence against this gene has been reported from other parts of the world (Tomar et al. 2014). It has been recommended that $L r 24$ should be used in combination of other $L r$ genes to prolong the life of this important gene for leaf rust resistance. $L r 24$ is also tightly linked to a stem rust resistance gene Sr24, which is effective even against the deadliest race TTKSK, popularly known as Ug99 (Singh et al. 2006). The presence of this gene pair in our derived progenies was confirmed using two stem rust pathotypes (34-1 and 40-1). Almost all the derived lines containing this gene pair were found to be completely resistant to the above two pathotypes (Table 3). The chromosomal segment of Ag. elongatum carrying the gene combination $L r 24 / S r 24$, besides providing resistance, has also been recently shown to be associated with improvement of most of the quality traits needed for making bread and other leavened products (Rai et al. 2021). Therefore, this gene pair could be safely utilized in wheat breeding program aimed at improving both the grain quality and rust resistance, as done during the present study.

Two derived progenies (Lok1-729-12 and Lok1-729-13) were resistant against all the 16 pathotypes of the three rusts including stem rust pathotypes 238S11 and 78S84 for which the donor genotype PBW343 (Gpc-B1/Yr36+Lr24) was susceptible (Fig. S2). This may be a case of disease escape for the above two progenies. It has been argued that the following gene combinations are effective in providing resistance against the prevalent pathotypes of the three rusts in India: (i) leaf rust ( $L r 24+L r 37+L r 76)$, (ii) stripe rust (Sr24+Sr38), and (iii) yellow rust ( $Y r 17+Y r 36+Y r 70)$. However, in recent years, new virulent races have emerged (Prasad et al. 2019). Among these new races, 77 were the most predominant and the pathotype 77-9 was the most prevalent in wheat leaf rust samples collected from India and Nepal. However, the pathotype 77-9 that is virulent to $L r 37$ could not overcome the resistance due to $L r 24$ (Table 3). Thus the transfer and pyramiding of $Y r 36$ and $L r 24$ genes along with $G p c-B 1$ gene (using the donor genotype PBW343+Gpc-B1/Yr36+Lr24) (Fig. 1) should prove useful for simultaneous improvement of grain quality and rust resistance.

Progenies in the background of cvs. PW550 + Yr15, PBW621 and DBW17. The recipient cvs. PBW 621 and DBW17 were susceptible or only moderately resistant to most of the pathotypes of the leaf and stripe rusts at the time of initiation of this study, although these were resistant to several stem rust pathotypes. However, the recipient parent PBW550 contained Yr15 gene that was already introgressed (this was later released for commercial cultivation in Punjab as PBW761 alias Unnat PBW550). Introgression of GpcB1/Yr36 gene in combination with Yr15 gave very strong field resistance to all prevalent stripe rust races in all progenies derived in the background of PBW550+Yr15. Progenies having GpcB1/Yr36 in the backgrounds of recipient cvs. PBW621 and DBW17 showed resistance to stripe rust owing to $Y r 36$ gene under natural field conditions. The progenies derived from all the three recipient genotypes were moderately resistant (10S to $20 \mathrm{~S}$ disease score; rarely $30 \mathrm{~S}$ ) to leaf rust under natural field conditions. This level of resistance of the derived progenies was similar to the level of resistance to leaf rust of the recurrent parents, although the availability of Lr genes for resistance to leaf rust in these genotypes is yet to be confirmed.

\section{Reconstitution of genotypes of recipients}

In the derived lines, the genome of the recurrent parents was reconstituted to the level of $90 \%$ to $96 \%$ (detailed data not presented), which is fairly high (Fig. $2 \mathrm{~d}$ ). The high RPG recovery matched with the recovery of phenotypic traits of the recipient parents, such that the introgressed lines and the recipient genotypes exhibited comparable values for agronomic traits including for 1000-grain weight and grain yield.

\section{Conclusions}

The present study, spread over 15 years, was undertaken jointly by five institutions located in the North, North-East, and Western parts of India. Since all the recipient cultivars used in the present study are popular and mega varieties adapted to various wheat growing agro-climatic zones of India and their contribution to national food security was immense, the improvement of these cultivars for grain quality and disease resistance through MABB is one of the major molecular breeding efforts undertaken in India. The developed progenies have the potential of developing into newer and improved cultivars for commercial cultivation or as pre-bred material for use in future wheat breeding programs.

\section{Declarations}

\section{Acknowledgements}

Thanks are due to the Department of Biotechnology, Government of India for the sanction of funds under different network projects. The faculty and research staff (including research fellows) involved in the present study received support from their respective institutions in various ways (including research fellowships under the network projects). PKG and HSB also received support from INSA (Indian National Science Academy).

\section{Funding}

Funds received from DBT (File No. DBT/PR11695/AGR/02/643/2008), New Delhi, India for carrying out this study.

\section{Author information}


Affiliations

Department of Genetics and Plant Breeding, Ch. Charan Singh University, Meerut-250004 (U.P.), India

Pushpendra K. Gupta, Harindra S. Balyan, Priyanka Agarwal, Sandhya Tyagi, Sachin Kumar, Tinku Gautam, , Vandana Jaiswal, Vijay Gahlaut

School of Agricultural Biotechnology, Punjab Agricultural University, Ludhiana-141004 (Punjab), India Parveen Chhuneja, Satinder Kaur

Deaprtment of Plant Breeding and Genetics, Punjab Agricultural University, Ludhiana-141004 (Punjab), India

Navtej S. Bains, Harinderjeet Kaur, Gurvinder S. Mavi, Achala Sharma, Puja Srivastava, Virinder S. Sohu, M. Shamshad

Deaprtment of Genetics and Plant Breeding, G.B. Pant University of Agriculture \& Technology, Pantnagar- 263145, U.S. Nagar (Uttarakhand) India

Jai P. Jaiswal, Moin Akhtar, Saurabh Badoni, Reeku Chaudhary, Rishi Pal Gangwar, Ravi Shankar Kumar, Anupama Singh

Agharkar Research Institute, Gopal Ganesh, Agarkar Rd, Shivajinagar, Pune-411004, (Maharashtra), India

S. Tamhankar, Manoj Oak

Department of Genetics and Plant Breeding, Institute of Agricultural Sciences, BHU, Varanasi-221005 (U.P.), India

Vinod K. Mishra, Ramesh Chand, Neeraj Kumar Vasistha, Manish Kumar Vishwakarma

Borlaug Institute for South Asia, G2, B Block, National Agricultural Science Centre Complex (NASC), Dev Prakash Shastri Marg New Delhi, Delhi 110012, India,

Arun K. Joshi

Regional Station, ICAR-Indian Institute of Wheat and Barley Research, Flowerdale, Shimla 171002, India

Pramod Prasad

Authors' contributions

PKG, HSB, PC, JPJ, ST, VKM conceived and designed the experiment. HSB prepared first draft of the MS. NSB, RC, AKJ, SK, HK, GSM, MO, AS, PS, VSS supervised the experimental at different centres. PA, MA, SB, RC, VG, RPG, TG, VJ, RSK, SK, MS, AS, ST, NKV, MKV carried out genotyping and phenotyping work at different centres. PP carried out rust screening of the pyramided lines.

Corresponding author

PK Gupta

Email id: pkgupta36@gmail.com

Ethics declarations

Not applicable

Ethics approval and consent to participate

Not applicable

Consent for publication

Not applicable

Availability of data and materials

Not applicable

Competing interests

The authors declare no competing interests.

\section{References}

1. Balyan HS, Gupta PK, Kumar S, Dhariwal R, Jaiswal V, Tyagi S, Agarwal P, Gahlaut V, Kumari S (2013) Genetic improvement of grain protein content and other health-related constituents of wheat grain. Plant Breed 132:446-457. https://doi.org/10.1111/pbr.12047

Page $8 / 16$ 
2. Brevis JC, Dubcovsky J (2010) Effect of chromosome region including the Gpc-B1 locus on wheat protein and protein yield. Crop Sci 50:93-104. https://doi.org/10.2135/cropsci2009.02.0057

3. Brevis JC, Morris CF, Manthey F, Dubcovsky J (2010) Effect of the grain protein content locus Gpc-B1 on bread and pasta quality. J Cereal Sci 51:357365. https://doi.org/10.1016/j.jcs.2010.02.004

4. Bhutia DT (2014) Protein energy malnutrition in India: the plight of our under five children. J Family Med Prim Care 3:63-67. https://doi.org/10.4103/2249-4863

5. Carter AH, Santra DK, Kidwell KK (2012) Assessment of the effects of the Gpc-B1 allele on senescence rate, grain protein concentration and mineral content in hard red spring wheat (Triticum aestivum L.) from the Pacific Northwest Region of the USA. Plant Breed 131:62-68. https://doi.org/10.1111/j.1439-0523.2011.01900.x

6. Collard BCY, Mackill DJ (2008) Marker-assisted selection: an approach for precision plant breeding in the twenty-first century. Phil Trans R Soc B 363:557-572. https://doi.org/10.1098/rstb.2007.2170

7. Dick JW, Quick JS (1983) A modified screening test for rapid estimation of gluten strength in early-generation durum wheat breeding lines. Cereal Chem 60:315-318

8. D’Ovidio R, Masci S (2004) The low-molecular-weight glutenin subunits of wheat gluten. J Cereal Sci 39:321-339. https://doi.org/10.1016/j.jcs.2003.12.002

9. Dhaka V, Khatkar BS (2015) Effects of gliadin/glutenin and HMW-GS/LMW-GS ratio on dough rheological properties and bread-making potential of wheat varieties. J Food Qual 38:71-82. https://doi.org/10.1111/jfq.12122

10. Dholakia BB, Ammiraju JSS, Santra DK et al (2001) Molecular marker analysis of protein con- tent using PCR-based markers in wheat. Biochem Genet 39:325-338. https://doi.org/10.1023/A:1012256813965

11. Distelfeld A, Cakmak I, Peleg Z et al (2007) Multiple QTL-effects of wheat Gpc-B1 locus on grain protein and micronutrient concen- trations. Physiol Plant 129:635-643. https://doi.org/10.1111/j.1399-3054.2006.00841.x

12. Distelfeld A, Uauy C, Fahima T, Dubcovsky J (2006) Physical map of the wheat high-grain protein content gene Gpc-B1 and development of a highthroughput molecular marker. New Phytol 169:753-763. https://doi.org/10.1111/j.1469-8137.2005.01627.x

13. Dobraszczyk BJ, Morgenstern MP (2003) Rheology and the breadmaking process. J Cereal Sci 38:229-245. https://doi.org/10.1016/S07335210(03)00059-6

14. Figueroa JDC, Maucher T, Reule W, Pena RJ (2009) Influence of high molecular weight glutenins on viscoelastic properties of intact wheat kernel and relation to functional properties of wheat dough. Cereal Chem 86:139-144. https://doi.org/10.1094/CCHEM-86-2-0139

15. Francia E, Tacconi G, Crosatti C, Barabaschi D, Bulgarelli D, Dall'Aglio E, Vale G (2005) Marker assisted selection in crop plants. Plant Cell Tiss Organ Cult 82:317-342. https://doi.org/10.1007/s11240-005-2387-z

16. Fu D, Uauy C, Distelfeld A, Blechl A, Epstein L, Chen X, Sela H, Fahima T, Dubcovsky J (2009) A kinase-START gene confers temperature dependent resistance to wheat stripe rust. Science 323:1357-1360. https://doi.org/10.1126/science.1166289

17. Gautam T, Dhillon GS, Saripalli G, Rakhi, Singh VP, Prasad P, Kaur S, Chhuneja P, Sharma PK, Balyan HS, Gupta PK (2020) Marker-assisted pyramiding of genes/QTL for grain quality and rust resistance in wheat (Triticum aestivum L.). Mol Breeding 40:49. https://doi.org/10.1007/s11032-020-01125-9

18. Gautam T, Amardeep, Saripalli G et al (2021) Introgression of a drought insensitive grain yield QTL for improvement of four Indian bread wheat cultivars using marker assisted breeding without background selection. J Plant Biochem Biotechnol 30:172-183. https://doi.org/10.1007/s13562-02000553-0

19. Giaever KO, Edvard H, Bjorndalen F (2017) A study of Marker assisted backcrossing (MAB) benefits of molecular markers in breeding. Int J Anim Breed Genet 6:1-17

20. Goel S, Singh K, Singh B et al (2019) Analysis of genetic control and QTL mapping of essential wheat grain quality traits in a recombinant inbred population. PLoS One 14:e0200669. https://doi.org/10.1371/journal.pone.0200669

21. Gras PW, Bekes F (1996) Small-scale testing: The development of instrumentation and application as a research tool. 506-510 in: Proc. 6th Int. Gluten Workshop. C. W. Wrigley, ed. RACl: North Melbourne, Australia

22. Gupta PK, Balyan HS, Sharma PC, Ramesh B (1998) Genetics and molecular biology of seed storage proteins in wheat. In: Ed. Gupta PK et al Genetics and Biotechnology in Crop Improvement. Rastogi Publications, Meerut, pp 126-157

23. Gupta PK, Balyan HS, Sharma S, Kumar R (2020) Genetics of yield, abiotic stress tolerance and biofortification in wheat (Triticum aestivum L.). Theor Appl Genet 133:1569-1602. https://doi.org/10.1007/s00122-020-03583-3

24. Gupta PK, Balyan HS, Sharma S, Kumar R (2021) Biofortification and bioavailability of Zn, Fe and Se in wheat: present status and future prospects. Theor Appl Genet 134:1-35. https://doi.org/10.1007/s00122-020-03709-7

25. Gupta PK, Kumar J, Mir RR, Kumar A (2010) Marker-assisted selection as a component of conventional plant breeding. Plant Breed Rev 33:145-2017. https://doi.org/10.1002/9780470535486.ch4

26. Hospital F (2003) Marker-assisted breeding. In: Newbury HJ (ed) Plant molecular breeding. Blackwell Publishing and CRC Press, Oxford, pp 30-59

27. Imtiaz M, Cromey MG, Hampton JG, Ahmad M (2003) Inheritance of durable adult plant resistance to stripe rust (Puccinia striiformis f. sp. tritici) in 'Otane' wheat (Triticum aestivum). New Zeal J Crop Hort 31:23-31. https://doi.org/10.1080/01140671.2003.9514232

28. Jiang GJ (2013) Molecular markers and marker-assisted breeding in plants. Intech Open access Book 'Plant Breeding from Laboratories to Fields', Chap. 3. http://dx.doi.org/10.5772/52583 4

Page 9/16 
29. Khan IA, Procunier JD, Humphreys DG et al (2000) Development of PCR- based markers for a high grain protein content gene from Triticum turgidum spp. Dicoccoides transferred to bread wheat. Crop Sci 40:518-524. https://doi.org/10.2135/cropsci2000.402518x

30. Krishnappa G, Singh AM, Chaudhary S et al (2017) Molecular mapping of the grain iron and zinc concentration, protein content and thousand kernel weight in wheat (Triticum aestivum L.). PLoS One 12:e0174972. https://doi.org/10.1371/journal. pone.0174972

31. Kulwal P, Kumar N, Kumar A, Gupta RK, Balyan HS, Gupta PK (2005) Gene networks in hexaploid wheat: interacting quantitative trait loci for grain protein content. Funct Integr Genomics 5:254-259. https://doi.org/10.1007/s10142-005-0136-3

32. Kumar N, Balyan HS, Gupta RK, Gupta PK (2006) Genetic analysis of grain protein content in bread wheat. J Genet Breed 60:29-36

33. Kumar J, Mir RR, Kumar N, Kumar A, Mohan A, Prabhu KV, Gupta PK (2010) Marker-assisted selection for pre-harvest sprouting tolerance and leaf rust resistance in bread wheat. Plant Breed 129:617-621. https://doi.org/10.1111/j.1439-0523.2009.01758.x

34. Kumar J, Jaiswal V, Kumar A et al (2011) Introgression of a major gene for high grain protein content in some Indian bread wheat cultivars. Field Crops Res 123:226-233. https://doi.org/10.1016/j.fcr.2011.05.013

35. Laemmli UK (1970) Cleavage of structural proteins during the assembly of the head of bacteriophage T4. Nature 227:680-685. https://doi.org/10.1038/227680a0

36. Mohan D, Tiwari V, Gupta RK (2017) Progression in yield and value addition of Indian bread wheat - An analysis. Indian J Genet 77:16-24. https://doi.org/10.5958/0975-6906.2017.00003.7

37. Murphy LR, Santra D, Kidwell K, Yan G, Chen X, Campbell KG (2009) Linkage maps of wheat stripe rust resistance genes Yr5 and Yr15 for use in MarkerAssisted Selection. Crop Sci 49:1786-1790. https://doi.org/10.2135/cropsci2008.10.0621

38. Nagarajan S, Tripathi S, Singh GP, Chaudhary HB (2007) Effect of genotype and environment on quality and grain yield of wheat. Indian J Genet 67:149-152. https://doi.org/10.1626/pps.15.192

39. Nucia A, Okon S. Tomczyn'ska-Mleko M (2019) Characterization of HMW glutenin subunits in European spring common wheat (Triticum aestivum L.). Genet Resour Crop Evol 66:579-588. https://doi.org/10.1007/s10722-018-00733-x

40. O’Brien L, Panozzo JF (1988) Breeding strategies for the simultaneous improvement of grain yield and protein content. In: T. E. Miller, and R. M. D. Koebner (eds), Proceedings of the 7th International Wheat Genetics Symposium, 13-18 July, 1143-1148 Institute of Plant Science Research, Cambridge, UK

41. Paltridge NG, Palmer LJ, Milham PJ, Guild GE, Stangoulis JCR (2012) Energy-dispersive X-ray fluorescence analysis of zinc and iron concentration in rice and pearl millet grain. Plant Soil 361:251-260. https://doi.org/10.1007/s11104-011-1104-4

42. Payne PI, Corfield KG, Blackman JA (1979) Identification of a high-molecular-weight subunit of glutenin whose presence correlates with bread-making quality in wheats of related pedigree. Theoret Appl Genet 55:153-159. https://doi.org/10.1007/BF00295442

43. Payne PI, Law CN, Mudd EE (1980) Control by homoeologous group 1 chromosomes of the high-molecular-weight subunits of glutenin, a major protein of wheat endosperm. Theor Appl Genet 58:113-120. https://doi.org/10.1007/BF00263101

44. Pearce S, Tabbita F, Cantu D et al (2014) Regulation of Zn and Fe transporters by the GPC1 gene during early wheat monocarpic senescence. BMC Plant Biol 14:368. https://doi.org/10.1186/s12870-014-0368-2

45. Peterson RF, Campbell AB, Hannah AE (1948) A diagrammatic scale for rust intensity on leaves and stems of cereals. Can J Res 26:496-500. https://doi.org/10.1139/cjr48c-033

46. Prabhu KV, Gupta SK, Charpe A, Koul S (2004) SCAR marker tagged to the alien leaf rust resistance gene Lr19 uniquely marking the Agropyron elongatum- derived gene Lr24 in wheat: a revision. Plant Breed 123:417-420. https://doi.org/10.1111/j.1439-0523.2004.00971.x

47. Prasad M, Varshney RK, Kumar A, Balyan HS, Sharma PC, Edwards KJ, Singh H, Dhaliwal HS, Roy JK, Gupta PK (1999) A microsatellite marker associated with a QTL for grain protein content on chromosome arm 2DL of bread wheat. Theor Appl Genet 99:341-345. https://doi.org/10.1007/s001220051242

48. Prasad M, Kumar N, Kulwal PL, Roder M, Balyan HS, Dhaliwal HS, Gupta PK (2003) QTL analysis for grain protein con- tent using SSR markers and validation studies using NILs in bread wheat. Theor Appl Genet 106:659-667. https://doi.org/10.1007/s00122-002-1114-y

49. Prasad P, Gangwar OP, Bharadwaj SC, Kumar S (2019) Monitoring pathotype distribution of Puccinia species on wheat and barley. Mehtaensis 39:5-9

50. Purugganan MD, Jackson SA (2021) Advancing crop genomics from lab to field. Nat Genet 53:595-560. https://doi.org/10.1038/s41588-021-00866-3

51. Patil Vr, Talati JG, Chandrakant S, Parekh V, Jadega G (2015) Genetic variation in glutenin protein composition of aestivum and durum wheat cultivars and Its relationship with dough quality. Int J Food Prop 18:2393-2408. https://doi.org/10.1080/10942912.2014.980948

52. Ram S (2003) High molecular weight glutenin subunit composition of Indian wheats and their relationships with dough strength. J Plant Biochem Biotechnol 12:151-155. https://doi.org/10.1007/BF03263177

53. Ram S, Sharma S, Sharma I (2015) Allelic diversity of HMW and LMW glutenins in Indian wheats and their relationship with sedimentation volume and mixograph parameters. Cereal Res Commn 43:492503. https://doi.org/10.1556/0806.43.2015.001

54. Rai A, Ahlawat AK, Shukla RB, Jain N, Kumar RR, Mahendru-Singh A (2021) Quality evaluation of near isogenic line of the wheat variety HD2733 carrying the Lr24/Sr24 genomic region. 3 Biotech 11:130. https://doi.org/10.1007/s13205-021-02679-x

55. Saghai-Maroof MA, Soliman KM, Jorgensen RA, Allard RW (1984) Ribosomal DNA spacer length polymorphisms in barley: Mendelian inheritance, chromosomal location, and population dynamics. Proc Natl Acad Sci USA 81:8014-8018. https://doi.org/10.1073/pnas.81.24.8014

56. Sharma A, Srivastava P, Mavi GS, Kaur S, Kaur J, Bala R, Singh TP, Sohu VS, Chhuneja P, Bains NS, Singh GP (2021) Resurrection of wheat cultivar PBW343 using marker-assisted gene pyramiding for rust resistance. Front Plant Sci 12:570408. https://doi.org/10.3389/fpls.2021.570408

Page $10 / 16$ 
57. Shewry PR, Hey SJ (2005) The Contribution of wheat to human diet and health. Food Energy Secur 4:178-202. https://doi.org/10.1002/fes3.64

58. Singh C, Srivastava P, Sharma A, Chhuneja P, Sohu VS, Bains NS (2018) Effect of Gpc-B1 gene on grain protein content and productivity traits in a set of high yielding wheat lines. Indian J Genet 78:211-216. https://doi.org/10.5958/0975-6906.2018.00027.5

59. Singh K, Batra R, Sharma S, Saripalli G, Gautam T, Rakhi, Kumar J, Pal S, Malik P, Kumar M, Lateef IJ, Singh S, Kumar D, Saksham, Chaturvedi D, Verma A, Rani A, Kumar A, Sharma H, Jyoti, Kumar K, Kumar S, Singh VK, Singh VP, Kumar S, Kumar R, Sharma S, Gaurav SS, Sharma PK, Balyan HS, Gupta PK (2021) WheatQTLdb: A QTL database for wheat. Mol Genet Genomics. https://doi.org/10.1007/s00438-021-01796-9

60. Singh RP, Hodson DP, Jin Y, Huerta-Espino J, Kinyua MG, Wanyera R, Njau P, Ward RW (2006) Current status, likely migration and strategies to mitigate the threat to wheat production from race Ug99 (TTKS) of stem rust pathogen. CAB Reviews 1:54. https://doi.org/10.1079/PAVSNNR20061054

61. Simmonds NW (1995) The relation between yield and protein in cereal grain. J Sci Food Agric 67:309-315. https://doi.org/10.1002/jsfa.2740670306

62. Stakman EC, Stewart DM, Loegering WQ (1962) Identification of races of Puccinia graminis var. tritici. U.S. Dept. of Agric. Publ. E617, USDA, Washington, DC, USA

63. Tabbita F, Pearce S, Barneix AJ (2017) Breeding for increased grain protein and micronutrient content in wheat: Ten years of the GPC-B1 gene. J Cereal Sci 73:181-191. https://doi.org/10.1016/j.jcs.2017.01.003

64. Tomar SMS, Singh SK, Sivasamy M, Vinod (2014) Wheat rusts in India: resistance breeding and gene deployment-a review. Indian J Genet Plant Breed 74:129-156. https://doi.org/10.5958/0975-6906.2014.00150.3

65. Tyagi S, Mir RR, Kaur H, Chhuneja P, Ramesh B, Balyan HS, Gupta PK (2014) Marker-assisted pyramiding of eight QTLs/ genes for seven different traits in common wheat (Triticum aestivum L.). Mol Breed 34:167-175. https://doi.org/10.1007/s11032-014-0027-1

66. Uauy C, Distelfeld A, Fahima T, Blechl A, Dubcovsky J (2006) A NAC gene regulating senescence improves grain protein, zinc and iron content in wheat. Science 314:1298-1301. https://doi.org/10.1126/science.1133649

\section{Tables}

Table 1. Mean and range values for five traits of the recipient parents and the MABB-derived progenies with significantly higher GPC. 


\begin{tabular}{|c|c|c|c|c|c|}
\hline $\begin{array}{l}\text { Recipient } \\
\text { parent/derived } \\
\text { progenies }\end{array}$ & $\begin{array}{l}\text { Mean } 1000-G W(g) \\
\text { (range) }\end{array}$ & $\begin{array}{l}\text { Mean GY (q/ha) } \\
\text { (range) }\end{array}$ & $\begin{array}{l}\text { Mean GPC } \\
(\%) \\
\text { (range) }\end{array}$ & $\begin{array}{l}\text { Mean Zn content } \\
(\mathrm{ppm}) \\
\text { (range) }\end{array}$ & $\begin{array}{l}\text { Mean Fe content } \\
\text { (ppm) } \\
\text { (range) }\end{array}$ \\
\hline Lok1 (R) & 51.9 & 40.20 & 12.02 & 19.83 & 29.07 \\
\hline \multirow[t]{2}{*}{ Progenies $(n=5)$} & 48.7 & 40.6 & 13.1 & 21.50 & 30.9 \\
\hline & $(44.0-55.1)$ & $(38.5-42.8)$ & $(12.9-13.3)$ & $(20.7-22.2)$ & $(29.6-32.5)$ \\
\hline HD2967 (R) & 42.9 & 50.60 & 12.90 & 21.50 & 30.80 \\
\hline \multirow[t]{2}{*}{ Progenies $(n=1)$} & 47.5 & 48.7 & 14 & 22.43 & 32.5 \\
\hline & $(-)$ & $(-)$ & $(-)$ & $(-)$ & $(-)$ \\
\hline MACS $2496(R)$ & 40.2 & 32.60 & 14.90 & NA & NA \\
\hline \multirow[t]{2}{*}{ Progenies $(n=12)$} & 38.4 & 28.9 & 16.50 & NA & NA \\
\hline & $(35.1-43.4)$ & $(23.00-38.30)$ & $(15.90-16.80)$ & & \\
\hline NI5439 (R ) & 36.9 & 46.09 & 13.87 & NA & NA \\
\hline \multirow[t]{2}{*}{ Progenies $(n=16)$} & 39.9 & 37.3 & 15.8 & NA & NA \\
\hline & $(32.4-46.9)$ & $(24.0-53.8)$ & $(14.8-17.2)$ & & \\
\hline DBW17(R) & 37.2 & 55.60 & 11.20 & NA & NA \\
\hline \multirow[t]{2}{*}{ Progeny $(n=1)$} & 36.3 & 53.2 & 13.80 & NA & NA \\
\hline & $(-)$ & $(-)$ & $(-)$ & & \\
\hline PBW550 (R) & 43.3 & 56.30 & 11.10 & 35.20 & 35.13 \\
\hline \multirow[t]{2}{*}{ Progenies $(n=3)$} & 40.87 & 51.36 & 13.6 & 37.78 & 37.12 \\
\hline & $(40.1-42.1)$ & $(50.40-53.10)$ & $(13.20-14.20)$ & $(31.5-46.6)$ & $(31.2-43.37)$ \\
\hline PBW621 (R) & 39.6 & 50.10 & 10.30 & 36.40 & 39.60 \\
\hline \multirow[t]{2}{*}{ Progenies $(n=01)$} & 35.4 & 47.30 & $13.70 *$ & $40.70 *$ & 35.40 \\
\hline & $(-)$ & $(-)$ & $(-)$ & $(-)$ & $(-)$ \\
\hline UP 2338 (R ) & 31.4 & 44.50 & 11.6 & NA & NA \\
\hline \multirow[t]{2}{*}{ Progenies $(n=6)$} & 37.0 & 50.90 & 13.1 & NA & NA \\
\hline & $(34.7-41.0)$ & $(48.2-52.5)$ & $(12.4-13.3)$ & & \\
\hline UP 2382 (R) & 31.8 & 46.60 & 11.60 & NA & NA \\
\hline \multirow[t]{2}{*}{ Progenies $(n=7)$} & 41.1 & 51.20 & 12.70 & NA & NA \\
\hline & $(40.20-43.0)$ & $(48.4-53.1)$ & $(12.1-13.2)$ & & \\
\hline HUW234 (R) & 36.5 & 45.30 & 11.70 & NA & NA \\
\hline \multirow[t]{2}{*}{ Progenies $(n=2)$} & 36.40 & 45.60 & 13.70 & NA & NA \\
\hline & $(36.2-36.6)$ & $(45.1-46.0)$ & $(13.6-13.8)$ & & \\
\hline HUW468 (R) & 32.6 & 40.5 & 11.1 & NA & NA \\
\hline \multirow[t]{2}{*}{ Progenies $(n=2)$} & 35.7 & 42.5 & 13.75 & NA & NA \\
\hline & $(35.2-36.2)$ & $(42.2-42.8)$ & $(13.7-13.8)$ & & \\
\hline
\end{tabular}

GW, grain weight; GY, grain yield; GPC, grain protein content; Zn, zinc; Fe, iron; R, recipient parent; $n$, number of progenies; NA, not available

Table 2. MAS-derived progenies (a) having significantly higher GPC, 1000-grain weight and no yield penalty in comparison to the respective recipient parents and (b) having significantly higher GPC, 1000-grain weight and grain yield in comparison to the respective recipient parents. 


\begin{tabular}{|c|c|c|c|}
\hline $\begin{array}{l}\text { Recipient parent/ } \\
\text { progeny }\end{array}$ & $1000-G W$ & GY (q/ha) & GPC(\%) \\
\hline \multicolumn{4}{|c|}{ (a) Significantly higher GPC, $1000-G W$ and no yield penalty } \\
\hline MAC2496 (R) & 42.0 & 32.6 & 14.9 \\
\hline MACS2496-22 & $47.2^{*}$ & 26.0 & $16.8^{*}$ \\
\hline MACS2496-45 & $43.4^{*}$ & 28.1 & $16.5^{\star}$ \\
\hline NI5439 (R) & 36.9 & 46.1 & 13.1 \\
\hline NI5439-2 & $41.2^{\star}$ & 44.3 & $15.0^{*}$ \\
\hline NI5439-6 & $42.2^{\star}$ & 50.1 & $14.9 *$ \\
\hline HUW468 (R) & 32.6 & 40.5 & 11.0 \\
\hline HUW468-358 & $35.5^{\star}$ & 46.6 & $12.2^{\star}$ \\
\hline HUW468-234 & $39.8 *$ & 46.5 & $14.0^{*}$ \\
\hline HUW468-258 & $40.3^{*}$ & 45.9 & $14.0^{*}$ \\
\hline \multicolumn{4}{|c|}{ (b) Significantly higher GPC, $1000-G W$ and grain yield } \\
\hline NI5439 (R) & 36.9 & 46.1 & 13.9 \\
\hline NI5439-6 & $39.6 *$ & $53.8^{*}$ & $16.0^{*}$ \\
\hline UP2338 (R) & 31.4 & 44.5 & 11.2 \\
\hline UP2338-14-1 & $34.9 *$ & $52.5^{\star}$ & $13.0^{*}$ \\
\hline UP2338-14-2 & $34.9 *$ & $52.1^{*}$ & $12.7 *$ \\
\hline UP2338-14-3 & $35.4^{*}$ & $51.6^{\star}$ & $13.3^{*}$ \\
\hline UP2338-14-4 & $35.9 *$ & $53.1^{\star}$ & $13.1^{*}$ \\
\hline UP2382 (R) & 31.8 & 46.6 & 11.6 \\
\hline UP2382-14-1 & $40.4^{\star}$ & $49.9 *$ & $13.2^{\star}$ \\
\hline UP2382-14-2 & $40.2^{\star}$ & $50.7 *$ & $12.4^{*}$ \\
\hline UP2382-14-3 & $40.8^{*}$ & $50.7^{\star}$ & $12.4^{*}$ \\
\hline UP2382-14-4 & $41.9 *$ & $52.4^{\star}$ & $12.4^{\star}$ \\
\hline UP2382-14-6 & $40.5^{\star}$ & $52.0^{*}$ & $13.0^{*}$ \\
\hline HUW468 (R) & 32.6 & 40.5 & 11.0 \\
\hline HUW468-358 & $35.5^{\star}$ & $42.8^{*}$ & $13.7^{*}$ \\
\hline HUW468-375 & $36.2^{\star}$ & $42.2^{\star}$ & $13.8^{*}$ \\
\hline
\end{tabular}

R, recipient parent; GW, grain weight; GY, grain yield; GPC, grain protein content; *, significantly higher at $5 \%$ level

Table 3. Summary of the results of screening of the parental genotypes and MAS-derived progenies (in the backgrounds of cvs. Lok1 and HD2967) against different pathotypes of the three rusts under glasshouse conditions. 


\begin{tabular}{|c|c|c|c|c|c|c|c|c|c|c|c|c|c|c|c|c|}
\hline \multirow[t]{2}{*}{ Genotype } & \multicolumn{5}{|c|}{ Leaf rust pathotypes } & \multicolumn{4}{|c|}{ Stripe rust pathotypes } & \multicolumn{7}{|c|}{ Stem rust pathotypes } \\
\hline & $\begin{array}{l}12- \\
5\end{array}$ & $\begin{array}{l}77- \\
5\end{array}$ & $\begin{array}{l}77- \\
8\end{array}$ & $\begin{array}{l}77- \\
9\end{array}$ & $2^{104-}$ & $238 S 119$ & $78 S 84$ & $\mathbf{T}$ & $110 S 119$ & 11 & $\begin{array}{l}21 A- \\
2\end{array}$ & $\begin{array}{l}34- \\
1\end{array}$ & $40 \mathrm{~A}$ & $\begin{array}{l}40- \\
1\end{array}$ & $\begin{array}{l}117- \\
6\end{array}$ & 122 \\
\hline Lok1 (R) & ; & $3^{+}$ & $3^{+}$ & 0 & $3^{+}$ & $3^{+}$ & 0 & $3^{+}$ & $3^{+}$ & $2^{-}$ & ; & - & $3^{+}$ & $;$ & - & ; \\
\hline Lok1-729-4 & ; & 0 & 0 & 0 & $;$ & 0 & 0 & 0 & 0 & $;$ & $;$ & $;$ & 2 & 3 & 0 & ; \\
\hline Lok1-729-11 & - & 0 & 0 & 0 & $12^{+}$ & 0 & 2 & 0 & $3^{+}$ & $2^{-}$ & $;$ & ; & $3+$ & 3 & ; & $3^{+}$ \\
\hline Lok1-729-12 & ; & 0 & $;$ & 0 & $;$ & 0 & 0 & ; & 0 & $;$ & $;$ & $;$ & $;$ & - & ; & $;$ \\
\hline Lok1-729-13 & 0 & 0 & $;$ & 0 & $;$ & 0 & $2^{-}$ & 0 & 0 & $2^{-}$ & $;$ & $;$ & $2^{-}$ & 12 & ; & $;$ \\
\hline Lok1-729-14 & $;$ & $3^{+}$ & 0 & 0 & $;$ & 0 & 0 & ; & 0 & $;$ & 0 & $;$ & 0 & $3^{+}$ & ; & 2 \\
\hline HD2967 (R) & 12 & $3^{+}$ & 0 & $3+$ & $3^{+}$ & $3^{+}$ & 0 & $3^{+}$ & $3^{+}$ & $3^{+}$ & 0 & 12 & 0 & 0 & 0 & $;$ \\
\hline HD2967-756 & $;$ & 0 & 0 & 0 & 0 & 3 & 0 & 0 & $3^{+}$ & $;$ & ; & ; & 0 & $;$ & 0 & 0 \\
\hline $\begin{array}{l}\text { PBW343(GpcB1/Yr36+Lr24) } \\
\text { (D) }\end{array}$ & ; & 0 & 0 & 0 & 0 & $3^{+}$ & 3 & 0 & $3^{+}$ & ; & $;$ & 0 & 0 & $;$ & ; & $;$ \\
\hline
\end{tabular}

IT, Infection type; 0 , indicate resistance; $2^{-}, 2^{+}$indicate moderately resistant; 3 , indicate moderately susceptible; $3^{+}$, indicates susceptible; - , data not available; $R$, recipient genotype; $D$, donor genotype.

\section{Figures}

RECIPIENT CULTIVARS (RCs)

LOK1, HD2967, MACS2496, PBW550 (Yr15),
PBW621, DBW17, UP2338, UP2382,
HUW234, HUW468, NI5439 HUW234, HUW468, NI5439
DONOR PARENTS

PBW343 (Gpc-B1/Yr36+Lr24),

Glupro (Gpc-B1Yr36)

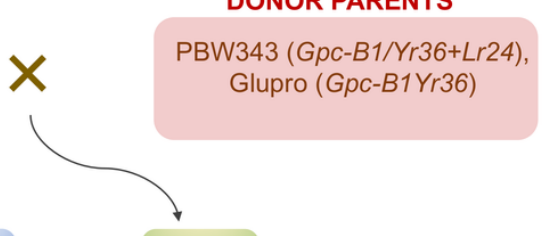

$\mathrm{RC} \times \underbrace{1 \mathrm{st} B C}$

\section{$\mathrm{RC}$}

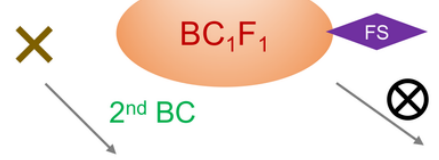

\section{$\mathrm{RC}$}

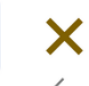

$3^{\text {rd } B C}$
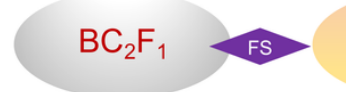

$\mathrm{BC}_{1} \mathrm{~F}_{2}$

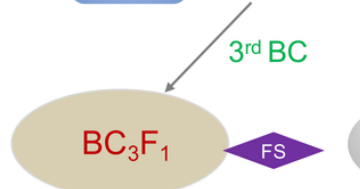

$\otimes$

$\otimes$

$\mathrm{BC}_{3} \mathrm{~F}_{1}$

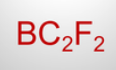

$\mathrm{BC}_{1} \mathrm{~F}_{3}$

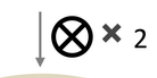

$\downarrow$

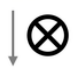

$\mathrm{BC}_{3} \mathrm{~F}_{3}$

$\mathrm{BC}_{2} \mathrm{~F}_{3}$

$\mathrm{BC}_{1} \mathrm{~F}_{4}$

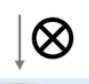

$\otimes \times 3$

$\otimes \times 3$

$\mathrm{BC}_{3} \mathrm{~F}_{4}$

$\mathrm{BC}_{2} \mathrm{~F}_{6}$

$\mathrm{BC}_{1} \mathrm{~F}_{7}$

Evaluation for GPC, HMW-GS and Agronomic traits

Figure 1 

cultivars.

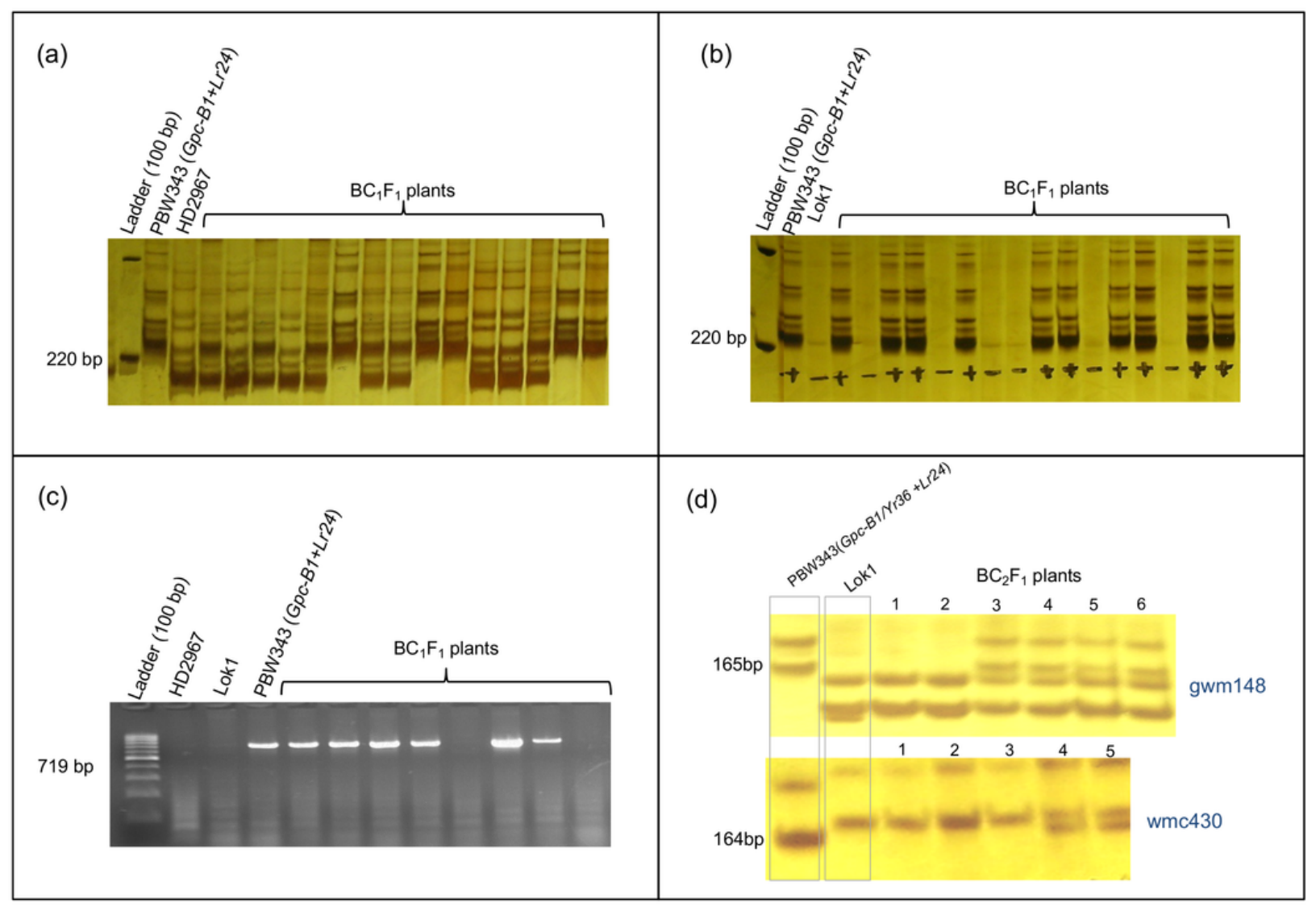

\section{Figure 2}

Representative amplification profiles of the markers (a \& b) UCW108 linked with Gpc-B1, (c) SCS73719 linked with Lr24 in recipient and donor parental lines and BC1F1 plants, and (d) Segregation for SSR markers (gwm148 and wmc430) used in background selection in BC2F1 population involving recipient genotype Lok1 and the donor genotype PBW343 (Gpc-B1/Yr36 +Lr24). 


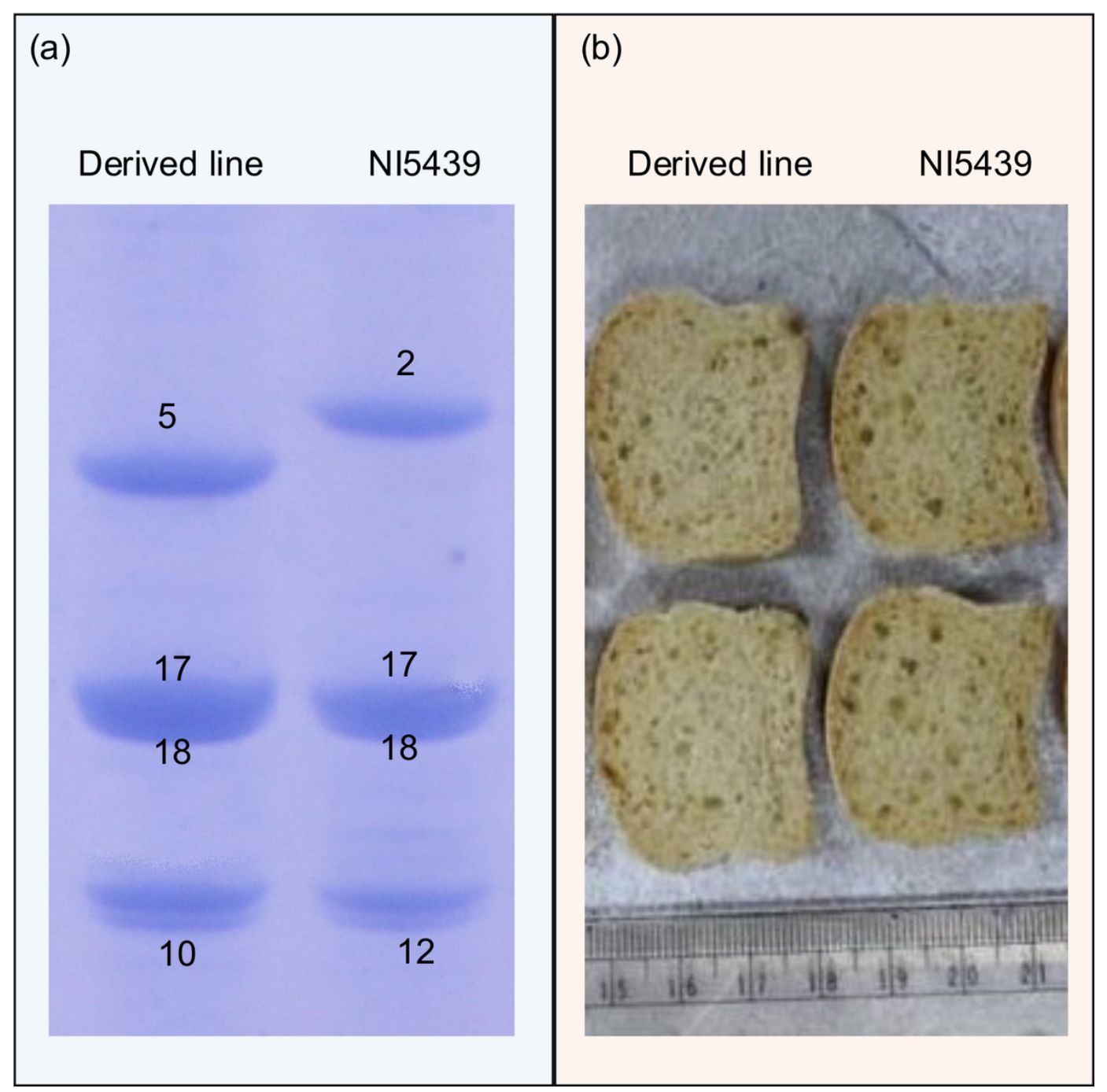

Figure 3

SDS-PAGE analysis of HMW-GS in the recipient cultivar NI5439 and the corresponding representative MABB-derived progeny containing HMW-GS $5+10$ combination. (b) Loaf volume of the bread prepared from recipient cultivar NI5439 and the corresponding representative MABB-derived progeny with high GPC and HMW-GS 5+10 combination.

\section{Supplementary Files}

This is a list of supplementary files associated with this preprint. Click to download.

- Supplementarymaterial.docx 